\section{Determining the MAXimum Speed limit in URBAN ROAD TO INCREASE TRAFFIC SAFETY}

Gito Sugiyantoa*, Siti Malkhamah

aCivil Engineering Department, Faculty of Engineering, Jenderal Soedirman University, Mayjend. Sungkono Street km 5, Blater, Kalimanah, Purbalingga, Central Java, Indonesia 53371

bCivil Engineering and Environment Department, Faculty of Engineering, Gadjah Mada University, Grafika Street No. 2, Yogyakarta, Indonesia 55281
Article history

Received

7 February 2017

Received in revised form

9 March 2018

Accepted

30 March 2018

Published online

1 August 2018

*Corresponding author gito.sugiyanto@unsoed.ac.id

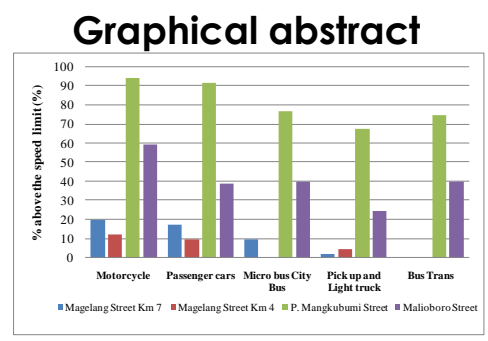

\begin{abstract}
Speed is one of the main risk factors in road traffic safety and become a traffic problem in developing countries. Three factors that cause accidents are human factor, vehicle, and environment. Speeding is one of the main cause factors in traffic accident. Traffic speed must be limited adjust with the activities in the street and potential accident. The aim of this research is to determine the maximum speed limit in urban road to increase traffic safety and to analyze the percentage of vehicle exceeding speed limit. The method to determine maximum speed limits using $85^{\text {th }}$ percentile. Based on the analysis result, the proposed maximum speed limit on urban road for arterial road type 4/2-UD residential and 4/2-UD CBD is $60 \mathrm{~km} / \mathrm{h}$ for motorcycle and passenger car, $55 \mathrm{~km} / \mathrm{h}$ for pick up and light truck, and $50 \mathrm{~km} / \mathrm{h}$ for bus and truck. Proposed maximum speed limit for collector road type 2/1-UD office area is $45 \mathrm{~km} / \mathrm{h}$ for motorcycle and $40 \mathrm{~km} / \mathrm{h}$ for four-wheeled vehicles or more while for collector road type $2 / 1-U D$ CBD is $40 \mathrm{~km} / \mathrm{h}$ for motorcycle and $35 \mathrm{~km} / \mathrm{h}$ for four-wheeled vehicles or more. The installation of speed limit sign is less effective to reduce the vehicle speed, the speed only reduce $2.9-5.5 \mathrm{~km} / \mathrm{h}$ (5.6-10.1\%). More than $46.5 \%$ of motorcycle users ride exceeding speed limit followed by the passenger cars users (39.43\%), microbus/city bus at $31.63 \%$, bus Trans at $28.75 \%$, pick up and light truck at $24.69 \%$. The maximum speed limit in school safety zone on hours/after school is $30 \mathrm{~km} / \mathrm{h}$ with the consideration that the pedestrian fatality rate on $30 \mathrm{~km} / \mathrm{h}$ has probability of death $10 \%$.
\end{abstract}

Keywords: Speed limit, traffic safety, speeding, traffic accident, pedestrian safety

(C) 2018 Penerbit UTM Press. All rights reserved

\subsection{INTRODUCTION}

Speed is one of the main risk factors in traffic safety [1]. It is difficult to examine the role of speed [2], higher speeds are proven to increase the likelihood of getting involved in a crash. Not only an increased chance of getting involved in crash, but the severity of crash also increases with speed, as the degree of kinetic energy at the time of the collision is higher [3]. Speed limits were introduced with the primary aim of reducing incidence, severity of casualty crashes [4], and reduces generalized cost [5]. This countermeasure was brought in with the aim of revealed that up to $30 \%$ of casualty crashes occur on residential streets [6]. Speed management is an important strategy to improve road safety [7, 8]. Speed limits enforcement is the main measure to control operating speeds [7], the speed acceptable to drivers [9]. TRL in 1994, found a relationship between speed and injury accidents- the higher speed, more accidents-indicating that $5 \%$ 
change in accidents was associated with a $1 \mathrm{mph}$ change in average speed [10].

The determination of the speed limit should consider the road conditions and areas along roadsides. About $20 \%$ of urban streets within Great Britain were designated 20 mph limits, and many other authorities planned to introduce low speed limits into their urban areas. The drivers of these policies may vary from city to city [11]. Australia lowered the speed limit for urban areas from 60 to $50 \mathrm{~km} / \mathrm{h}$ have been shown to reduce the risk from accidents, revealed significant reductions in both fatal and serious injury crashes, and substantial overall social cost savings. Crash reductions in $50 \mathrm{~km} / \mathrm{h}$ zones, relative to changes observed in crash frequency in all speed zones remaining $60 \mathrm{~km} / \mathrm{h}$ in South East Queensland for various crash severity levels. On average, statistically significant yearly estimated reductions of $22 \%$ for all reported crashes, $20 \%$ for all property damage crashes, $23 \%$ for all casualty crashes, $24 \%$ for serious casualty crashes, and $88 \%$ for fatal crashes [4].

Traffic safety is a social problem that handling must be done comprehensively. Traffic speed must be limited adjust with the activities in the street and potential accident. Speeding-which encompasses excessive speed or inappropriate speed, is dangerous. speed is an aggravating factor in the severity of all accidents [3]. Speeding was the main human error that contributed $57 \%$ to the crashes. In Thailand, cases involving vehicle hitting trees be the most serious and resulting 48 fatalities [12]. If the terms of the performance of traffic, the higher speed will improve traffic performance, opposite from the aspect of traffic safety, speed will decrease the degree of safety because of the risk of accidents becomes greater. Lowered speed limit reduces the risk from accident; reduce the externality cost like accident cost [13]. The cost of accidents can be decreased by reducing the frequency of accidents and severity of injury [14]. Total accident cost in Purbalingga Regency, Central Java, Indonesia was estimated $0.38 \%$ of the gross domestic product [15]. It is necessary for the determination of the maximum speed limit of vehicle as mandated in Indonesian Law No. 22 of 2009 on different types of road function, the type of terrain, and types of land use and the level of activity [16].

Research related to the speed limit and the risk of accidents concluded that lowered the speed limit will reduce the average driving speed, the number of accidents and the severity. The study of Roads and Traffic Authority (RTA) in New South Wales, after implementation speed limit, found that on $50 \mathrm{~km} / \mathrm{h}$ streets there was a $25.3 \%$ reduction crashes and mean travelling speeds drop $0.94 \mathrm{~km} / \mathrm{h}$ (RTA, 2000 in [17]). In Queensland, reductions $8 \%$ in casualties overall, $18 \%$ in fatalities, and mean travelling speeds dropping by 5 $\mathrm{km} / \mathrm{h}$ (Walsh and Smith, 1999 in [17]). The establishment of speed limits in urban areas in Victoria reduced traffic accidents by $12 \%$ [4]. In Queensland, default of speed limits at $50 \mathrm{~km} / \mathrm{h}$, the relationship between the speeds with risk of injury due to accidents concluded that overall changes in average speed for every 1 $\mathrm{km} / \mathrm{h}$ will change the risk of accidents about $3 \%$. Andersson and Nilsson (1997) concluded that severity of injuries and fatalities changed along with changes in average speed [4]. According to the initial speed limit, through the application of two models an exponential function and power model, slightly higher support was given to the exponential function, which showed an increase of 1.58 in the number of fatal crashes if speed increased with $1 \mathrm{~km} / \mathrm{h}$ from an initial speed of $85 \mathrm{~km} / \mathrm{h}$. The number of injury crashes was estimated to increase with 1.21. Starting from an initial speed of $75 \mathrm{~km} / \mathrm{h}$ an increase of 0.79 fatal crashes with an increase by $1 \mathrm{~km} / \mathrm{h}$ was found, for the injury crashes this was 0.86 [18].

Increasing vehicle speed affect to the increased reaction time and distance it takes to stop and increased likelihood of errors that can be carried by the driver. Pedestrians, incur a risk of about $80 \%$ of being killed at a collision speed of $50 \mathrm{~km} / \mathrm{h}$. Wearing seat-belts and using well-designed cars for car occupants generally can provide protection to a maximum of $70 \mathrm{~km} / \mathrm{h}$ in frontal impacts, and $50 \mathrm{~km} / \mathrm{h}$ in most side impacts (Tingvall et al., 1999 in [19]. Probability of fatal injury for a pedestrian colliding with a vehicle shown in Figure 1.

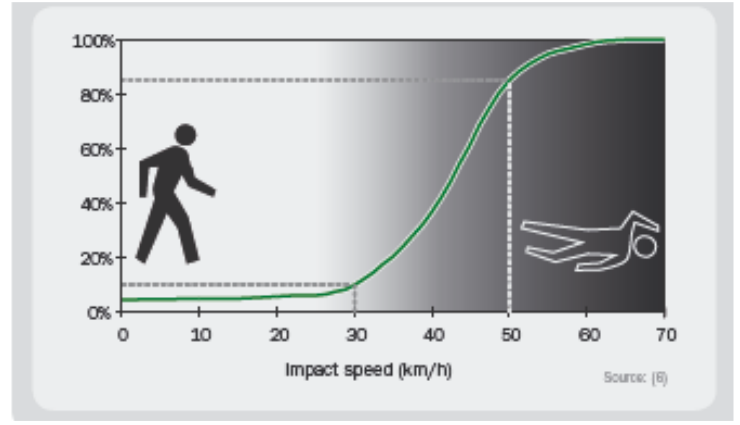

Figure 1 Probability of fatal injury for a pedestrian colliding with a vehicle [3]

High speeds increase the risk of accidents. Australian Transport Safety Bureau stated that the reaction time can be as little as 1 second but mostly ranged from 1.5 up to 4 seconds [19]. Illustration stopping distances in an emergency braking is shown in Figure 2.

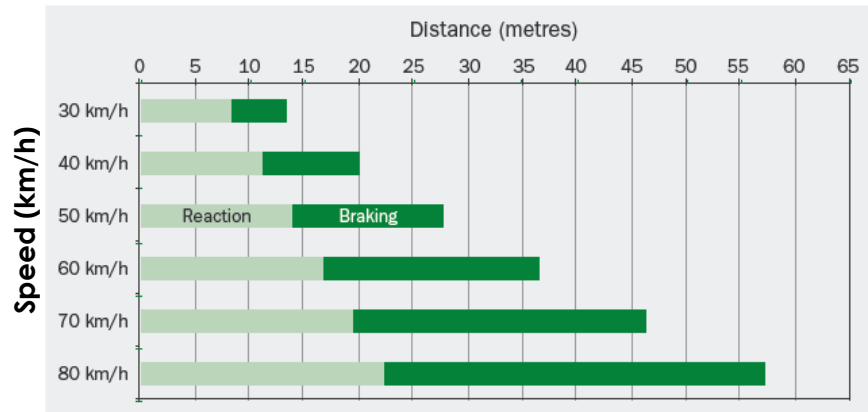

Figure 2 Illustration stopping distance in an emergency braking [19] 
Based on the procedure traffic handbook was issued by Directorate General of Land Transportation, Minister of Transportation Republic of Indonesia in 2005, the risk of driving at high speeds raise the risk involved in a traffic accident [20]. At a speed of $50 \mathrm{~km} / \mathrm{h}$ the car will be needed $41 \mathrm{~m}$ to stop, but at a speed of $60 \mathrm{~km} / \mathrm{h}$ takes a distance of $58 \mathrm{~m}$ to stop. This makes the difference is quite noticeable on the opportunities accidents involved motorists. Traffic accident locations have an effect on the severity [21].

The aim of this study is to determine the maximum speed limit of vehicles on urban roads and to analyze the application trial of maximum speed limit to know the percentage of vehicle that exceeding the speed limit and its impact on pedestrian safety.

\subsection{METHODOLOGY}

\subsection{Study Location}

The study location is in Special Region of Yogyakarta Province, Indonesia. Study location in four streets: Magelang Street km 7 and Magelang Street km 4 is an arterial road in urban area; Pangeran Mangkubumi Street and Malioboro Street is collector road. The location of study can be seen in Figure 3 .

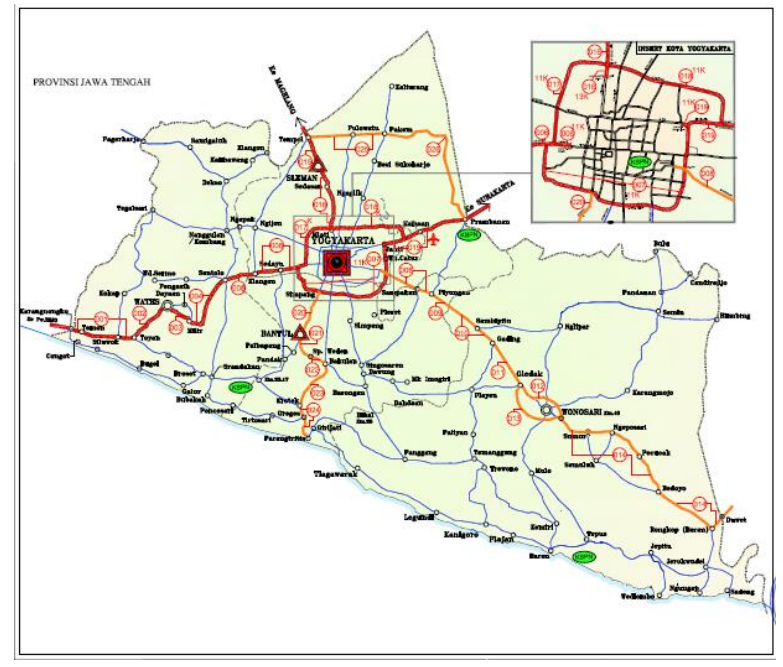

Figure 3 Location of study in Special Region of Yogyakarta Province

\subsection{Data Collection and Analysis}

Maximum speed limit data in arterial and collector road obtained from Department of Transportation Special Region of Yogyakarta Province. Vehicle speed of motorcycle, passenger car, pick up and light truck, microbus, bus, TransJogja bus, truck, and trailer truck obtained in the field using speed gun. The statistical analysis of vehicle speeds results, include the mean, mode, median, variance, standard deviation, the amount of data, and $15^{\text {th }}, 50^{\text {th }}, 85^{\text {th }}$, and $98^{\text {th }}$ percentiles for each type of vehicles. The determination of the maximum speed limit based on vehicle speed at the $85^{\text {th }}$ percentile is distinguished by the type of land use i.e.: school area, residential area, Central Business District (CBD), hotel, shop, market, and industrial district. The impact of reducing speed limit was analysis on vehicle percentage that violating the speed limit and impact in pedestrian safety.

\subsection{RESULTS AND DISCUSSION}

\subsection{Analysis of Vehicle Speed}

\section{a. Vehicle Speed in Magelang Street km 7, Sleman}

Magelang street $\mathrm{km} \mathrm{7.} \mathrm{Sleman} \mathrm{is} \mathrm{an} \mathrm{arterial} \mathrm{road,}$ consists of 4 lanes 2 directions without median or undivided road (4/2 UD) with land use as a residential area, shops, and office. The wide of this road is $12.00 \mathrm{~m}$ with the road capacity is $4132 \mathrm{pcu} / \mathrm{h}$. The maximum speed limit of vehicles in Magelang street $\mathrm{km} 7$, Sleman is $60 \mathrm{~km} / \mathrm{h}$. The number of vehicles has taken as many as 643 vehicles, with an S-curve of vehicle speed as shown in Figure 4. The type of vehicles in the field was dominated by motorcycles (52.10\%) followed by passenger cars (29.86\%). Based on Figure 4, it can be seen that $17.25 \%$ of passenger cars users and $19.75 \%$ of motorcycle users exceed the maximum speed limit in the field is $60 \mathrm{~km} / \mathrm{h}$. In addition to passenger cars and motorcycles, the types of vehicles that exceed the maximum speed limit are bus (9.5\%), pick-up and light truck with a percentage of approximately $2 \%$. The statistical analysis of vehicle speeds results, include the mean, mode, median, variance, standard deviation, the amount of data, and $15^{\text {th }}, 50^{\text {th }}, 85^{\text {th }}$, and $98^{\text {th }}$ percentiles for each type of vehicles in Table 1.

The average speed of motorcycle at $51 \mathrm{~km} / \mathrm{h}$, passenger car at $52 \mathrm{~km} / \mathrm{h}$, pick up and light truck at $45.4 \mathrm{~km} / \mathrm{h}$, microbus at $41.1 \mathrm{~km} / \mathrm{h}$, bus at $43.2 \mathrm{~km} / \mathrm{h}$, truck at $41.5 \mathrm{~km} / \mathrm{h}$, and trailer truck at $34.2 \mathrm{~km} / \mathrm{h}$. The average speed from 643 vehicles is $49.8 \mathrm{~km} / \mathrm{h}$. This value is smaller than the maximum speed limit in the field $(60 \mathrm{~km} / \mathrm{h})$. The speed limit based on $85^{\text {th }}$ percentile varied between $36.8 \mathrm{~km} / \mathrm{h}$ for trailers truck up to $64 \mathrm{~km} / \mathrm{h}$ for motorcycles. The speed limit value based on $85^{\text {th }}$ percentile for motorcycle $(64 \mathrm{~km} / \mathrm{h})$ and passenger car $(62 \mathrm{~km} / \mathrm{h})$ is higher than the maximum speed limit in the field $(60 \mathrm{~km} / \mathrm{h})$. 


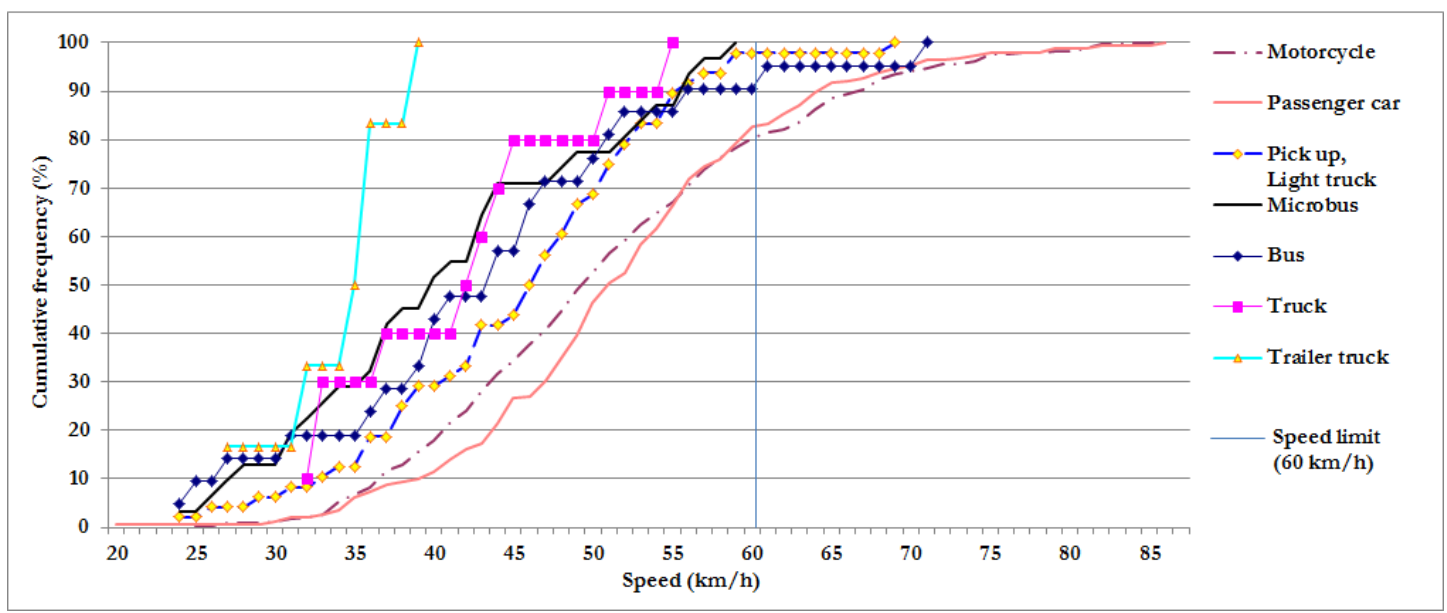

Figure 4 S-curve of vehicle speed in Magelang street km 7, Sleman

Table 1 Characteristics and statistical analysis of vehicle speed in Magelang street km. 7, Sleman

\begin{tabular}{|c|c|c|c|c|c|c|c|c|c|}
\hline \multicolumn{2}{|c|}{ Statistical analysis } & $\begin{array}{l}\text { Motor } \\
\text { cycle }\end{array}$ & $\begin{array}{c}\text { Passenger } \\
\text { car }\end{array}$ & $\begin{array}{c}\text { Pick up, } \\
\text { Light truck }\end{array}$ & $\begin{array}{c}\text { Micro } \\
\text { bus }\end{array}$ & Bus & Truck & $\begin{array}{c}\text { Trailer } \\
\text { truck }\end{array}$ & Total \\
\hline \multicolumn{2}{|l|}{ Mean $(\mathrm{km} / \mathrm{h})$} & 51.0 & 52.0 & 45.4 & 41.1 & 43.2 & 41.5 & 34.2 & 49.8 \\
\hline \multicolumn{2}{|l|}{ Modus (km/h) } & 49.0 & 50.0 & 43.0 & 37.0 & 40.0 & 33.0 & 36.0 & 49.0 \\
\hline \multicolumn{2}{|l|}{ Median (km/h) } & 50.0 & 51.0 & 46.5 & 40.0 & 44.0 & 42.5 & 35.5 & 49.0 \\
\hline \multicolumn{2}{|l|}{ Variance $(\mathrm{km} / \mathrm{h})$} & 131.7 & 107.3 & 84.9 & 98.8 & 135.7 & 60.9 & 17.4 & 128.7 \\
\hline \multicolumn{2}{|c|}{ Standard deviation (SD) } & 11.5 & 10.4 & 9.2 & 9.9 & 11.6 & 7.8 & 4.2 & 11.3 \\
\hline \multicolumn{2}{|l|}{ Amount of data (n) } & 335 & 192 & 48 & 31 & 21 & 10 & 6 & 643 \\
\hline \multirow[t]{4}{*}{ Percentile (km/h) } & 15 & 39.0 & 42.0 & 36.0 & 31.0 & 31.0 & 33.0 & 30.8 & 38.0 \\
\hline & 50 & 50.0 & 51.0 & 46.5 & 40.0 & 44.0 & 42.5 & 35.5 & 49.0 \\
\hline & 85 & 64.0 & 62.0 & 54.9 & 53.5 & 52.0 & 48.9 & 36.8 & 61.0 \\
\hline & 98 & 77.6 & 75.7 & 59.6 & 57.8 & 67.0 & 54.3 & 38.7 & 75.0 \\
\hline
\end{tabular}

\section{b. Vehicle Speed in Magelang Street $\mathrm{km} \mathrm{4}$, Yogyakarta}

Magelang street $\mathrm{km} \mathrm{4,} \mathrm{Yogyakarta} \mathrm{is} \mathrm{an} \mathrm{arterial} \mathrm{road}$ in urban area consists of 4 lanes 2 directions without median or undivided road (4/2 UD) with land use as a central business district, residential area, shops, and office with maximum speed limit of $60 \mathrm{~km} / \mathrm{h}$. The wide of this road is $14.00 \mathrm{~m}$ with the road capacity is 5712 $\mathrm{pcu} / \mathrm{h}$. The number of vehicles has taken as many as 717 vehicles, with an S-curve of vehicles speed as shown in Figure 5. The type of vehicles in the field was dominated by motorcycles $(55.79 \%)$ followed by passenger cars $(27.89 \%)$. The statistical analysis of vehicle speeds results, include the mean, mode, median, variance, standard deviation, the amount of data, and $15^{\text {th }}, 50^{\text {th }}, 85^{\text {th }}$, and $98^{\text {th }}$ percentiles for each type of vehicle in Table 2 . The average speed of motorcycle at $48.3 \mathrm{~km} / \mathrm{h}$, passenger car at 48.3 $\mathrm{km} / \mathrm{h}$, pick up and light truck at $43.6 \mathrm{~km} / \mathrm{h}$, microbus at $33.1 \mathrm{~km} / \mathrm{h}$, and truck at $43.5 \mathrm{~km} / \mathrm{h}$. The average speed from 717 vehicles is $47.1 \mathrm{~km} / \mathrm{h}$. This value is smaller than maximum speed limit in the field 160 $\mathrm{km} / \mathrm{h})$. Standard deviation value varied between 8.7 for passenger car up to 10.8 for pick-up and light truck. The speed limit on $85^{\text {th }}$ percentile varied between $41.8 \mathrm{~km} / \mathrm{h}$ for microbus up to $59 \mathrm{~km} / \mathrm{h}$ for motorcycle. Based on Figure 5, it can be seen that $10 \%$ of passenger cars users and $12.25 \%$ of motorcycle users exceed the maximum speed limit specified in the field is $60 \mathrm{~km} / \mathrm{h}$. In addition to passenger cars and motorcycles, the type of vehicles that exceed the maximum speed limit is pick-up and light truck with a percentage of approximately $4.75 \%$. 


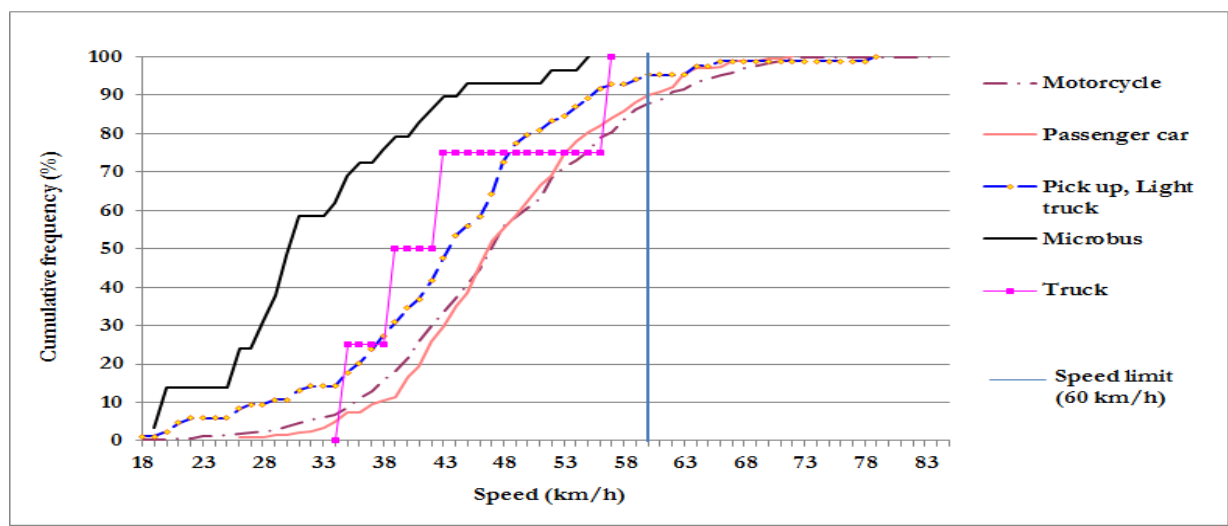

Figure 5 S-curve of vehicle speed in Magelang street km. 4, Yogyakarta

Table 2 Characteristics and statistical analysis of vehicle speed in Magelang Street km. 4, Yogyakarta

\begin{tabular}{|c|c|c|c|c|c|c|c|}
\hline \multicolumn{2}{|c|}{ Statistical analysis } & $\begin{array}{l}\text { Motor } \\
\text { cycle }\end{array}$ & $\begin{array}{c}\text { Passenger } \\
\text { car }\end{array}$ & $\begin{array}{c}\text { Pick up, } \\
\text { Light truck }\end{array}$ & Microbus & Truck & Total \\
\hline \multicolumn{2}{|l|}{ Mean (km/h) } & 48.3 & 48.3 & 43.6 & 33.1 & 43.5 & 47.1 \\
\hline \multicolumn{2}{|l|}{ Modus (km/h) } & 47.0 & 46.0 & 48.0 & 20.0 & N/A & 47.0 \\
\hline \multicolumn{2}{|l|}{ Median (km/h) } & 47.0 & 47.0 & 44.0 & 33.0 & 41.0 & 47.0 \\
\hline \multicolumn{2}{|l|}{ Variance $(\mathrm{km} / \mathrm{h})$} & 105.8 & 75.2 & 116.9 & 79.8 & 91.7 & 107.4 \\
\hline \multicolumn{2}{|c|}{ Standard deviation (SD) } & 10.3 & 8.7 & 10.8 & 8.9 & 9.6 & 10.4 \\
\hline \multicolumn{2}{|l|}{ Amount of data (n) } & 400 & 200 & 84 & 29 & 4 & 717 \\
\hline \multirow[t]{4}{*}{ Percentile $(\mathrm{km} / \mathrm{h})$} & 15 & 38.0 & 40.0 & 35.0 & 26.0 & 36.8 & 37.0 \\
\hline & 50 & 47.0 & 47.0 & 44.0 & 33.0 & 41.0 & 47.0 \\
\hline & 85 & 59.0 & 58.0 & 53.6 & 41.8 & 50.7 & 58.0 \\
\hline & 98 & 70.0 & 67.0 & 64.7 & 53.3 & 56.2 & 68.7 \\
\hline
\end{tabular}

\section{c. Vehicle Speed in Pangeran Mangkubumi Street, Yogyakarta}

Pangeran Mangkubumi Street, Yogyakarta is a collector road in urban area with maximum speed limit of $30 \mathrm{~km} / \mathrm{h}$. This street consists of 2 lanes 1 direction without median or undivided road (2/1 UD) with land use as CBD, hotel, shops, and office. The wide of this road is $7.00 \mathrm{~m}$ with the road capacity is $2348 \mathrm{pcu} / \mathrm{h}$. The number of vehicles has taken as many as 751 vehicles, with an S-curve of vehicle speed as shown in Figure 6. The type of vehicles in the field was dominated by motorcycles (55.92\%) followed by passenger cars (31.96\%).

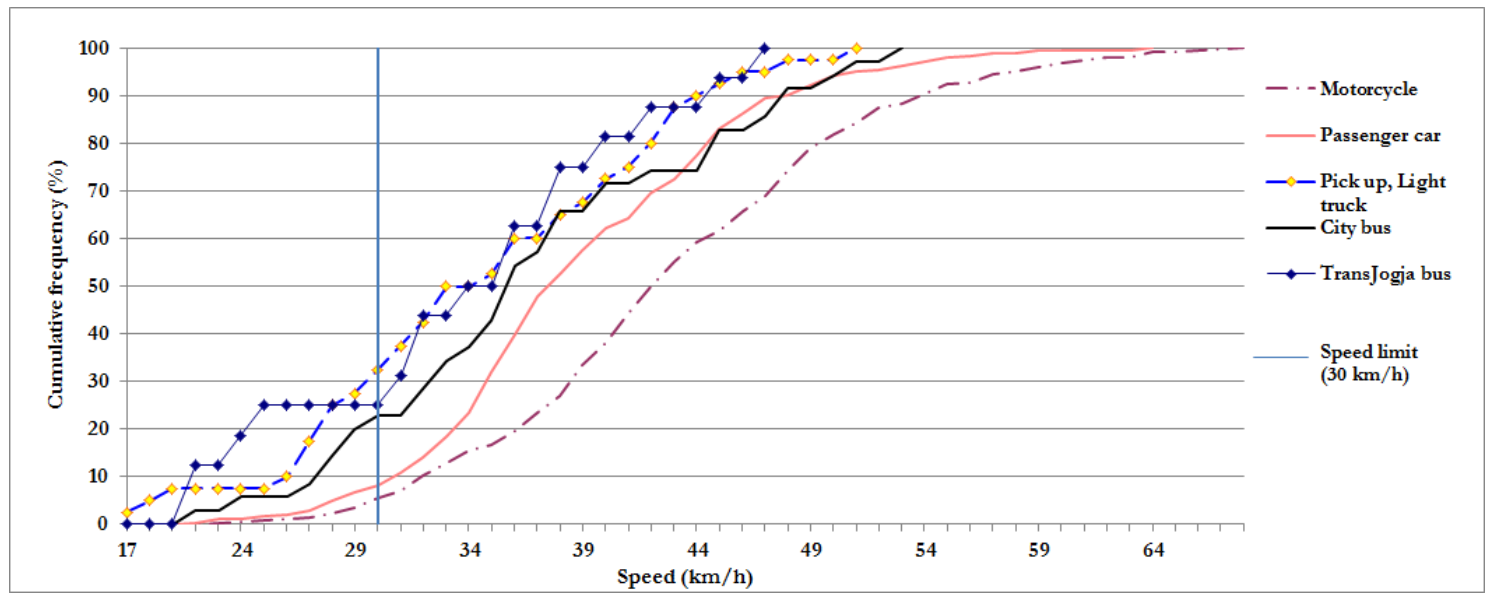

Figure 6 S-curve of vehicle speed in Pangeran Mangkubumi Street, Yogyakarta 
Table 3 Characteristics and statistical analysis of vehicle speed in Pangeran Mangkubumi Street, Yogyakarta

\begin{tabular}{|c|c|c|c|c|c|c|c|}
\hline \multicolumn{2}{|c|}{ Statistical analysis } & $\begin{array}{l}\text { Motor } \\
\text { cycle }\end{array}$ & $\begin{array}{c}\text { Passenger } \\
\text { car }\end{array}$ & $\begin{array}{c}\text { Pick up, } \\
\text { Light truck }\end{array}$ & City bus & TransJogja & Total \\
\hline \multicolumn{2}{|l|}{ Mean $(\mathrm{km} / \mathrm{h})$} & 43.3 & 39.2 & 34.7 & 37.1 & 34.0 & 41.1 \\
\hline \multicolumn{2}{|l|}{ Modus (km/h) } & 39.0 & 35.0 & 27.0 & 36.0 & 22.0 & 36.0 \\
\hline \multicolumn{2}{|l|}{ Median $(\mathrm{km} / \mathrm{h})$} & 42.5 & 38.0 & 34.0 & 36.0 & 35.0 & 40.0 \\
\hline \multicolumn{2}{|l|}{ Variance $(\mathrm{km} / \mathrm{h})$} & 70.8 & 49.3 & 64.3 & 62.8 & 61.1 & 70.6 \\
\hline \multicolumn{2}{|l|}{ Standard deviation (SD) } & 8.4 & 7.0 & 8.0 & 7.9 & 7.8 & 8.4 \\
\hline \multicolumn{2}{|l|}{ Amount of data (n) } & 420 & 240 & 40 & 35 & 16 & 751 \\
\hline \multirow[t]{4}{*}{ Percentile (km/h) } & 15 & 34.0 & 33.0 & 27.0 & 29.0 & 24.3 & 33.0 \\
\hline & 50 & 42.5 & 38.0 & 34.0 & 36.0 & 35.0 & 40.0 \\
\hline & 85 & 52.0 & 46.0 & 43.0 & 46.8 & 41.5 & 49.0 \\
\hline & 98 & 62.6 & 55.2 & 48.7 & 51.6 & 46.4 & 60.0 \\
\hline
\end{tabular}

Speed limit violations are very common. There are $67 \%$ to $94.5 \%$ of the drivers exceed the limit. Based on Figure 6 , it can be seen that $94.5 \%$ of motorcycle users, $91.67 \%$ of passenger cars users, $77 \%$ of city bus, $75 \%$ of Trans Jogja bus, and $67.5 \%$ of pick up and light truck exceed the maximum speed limit specified in the field is $30 \mathrm{~km} / \mathrm{h}$. The statistical analysis of vehicle speeds results, include the mean, mode, median, variance, standard deviation, the amount of data, and $15^{\text {th }}, 50^{\text {th }}, 85^{\text {th }}$, and $98^{\text {th }}$ percentiles for each type of vehicle shown in Table 3 . The average speed of motorcycle at $43.3 \mathrm{~km} / \mathrm{h}$, passenger car at $39.2 \mathrm{~km} / \mathrm{h}$, pick up and light truck at $34.7 \mathrm{~km} / \mathrm{h}$, City bus at 37.1 $\mathrm{km} / \mathrm{h}$, and TransJogja bus $34 \mathrm{~km} / \mathrm{h}$. The average speed from 751 vehicles is $41.1 \mathrm{~km} / \mathrm{h}$. This value is greater than the maximum speed limit in the field (30 $\mathrm{km} / \mathrm{h}$ ). Standard deviation value varied between 7 for passenger car up to 8.4 for motorcycle. The speed limit on $85^{\text {th }}$ percentile varied between $41.5 \mathrm{~km} / \mathrm{h}$ for Trans Jogja bus up to $52 \mathrm{~km} / \mathrm{h}$ for motorcycle.

\section{d. Vehicle Speed in Malioboro Street, Yogyakarta}

Malioboro Street, Yogyakarta is a collector road in urban area with maximum speed limit of $30 \mathrm{~km} / \mathrm{h}$. This street consists of 2 lanes 1 direction without median or undivided road (2/1 UD) with land use as a central business district, hotel, shops, market, and office. The wide of this road is $7.00 \mathrm{~m}$ with the road capacity is $1941 \mathrm{pcu} / \mathrm{h}$. The number of vehicles has taken as many as 745 vehicles, with an S-curve of vehicle speed as shown in Figure 7. The type of vehicles in the field was dominated by motorcycles (53.69\%) followed by passenger cars (33.56\%). Speed limit violations are very common. Among $24-60 \%$ of the drivers exceed the limit. Based on Figure 7 , it can be seen that $59.5 \%$ of motorcycle users, $38.8 \%$ of passenger cars users, $40 \%$ of city bus, $40 \%$ of TransJogja bus, and $24.5 \%$ of pick up and light truck exceed the maximum speed limit specified in the field is $30 \mathrm{~km} / \mathrm{h}$. The statistical analysis of vehicle speeds results, include the mean, mode, median, variance, standard deviation, the amount of data, and $15^{\text {th }}, 50^{\text {th }}, 85^{\text {th }}$, and $98^{\text {th }}$ percentiles for each type of vehicle shown in Table 4.

The average speed of motorcycle at $33.1 \mathrm{~km} / \mathrm{h}$, passenger car at $28.5 \mathrm{~km} / \mathrm{h}$, pick up or light truck at $25.7 \mathrm{~km} / \mathrm{h}$, City bus at $28.1 \mathrm{~km} / \mathrm{h}$, and TransJogja bus at $29.5 \mathrm{~km} / \mathrm{h}$. The average speed from 745 vehicles is $30.8 \mathrm{~km} / \mathrm{h}$. This value is greater than the maximum speed limit in the field $(30 \mathrm{~km} / \mathrm{h})$. Standard deviation value varied between 5.6 for TransJogja up to 8 for motorcycle. The speed limit on $85^{\text {th }}$ percentile varied between $33 \mathrm{~km} / \mathrm{h}$ for pick up or light truck up to 41 $\mathrm{km} / \mathrm{h}$ for motorcycle. 


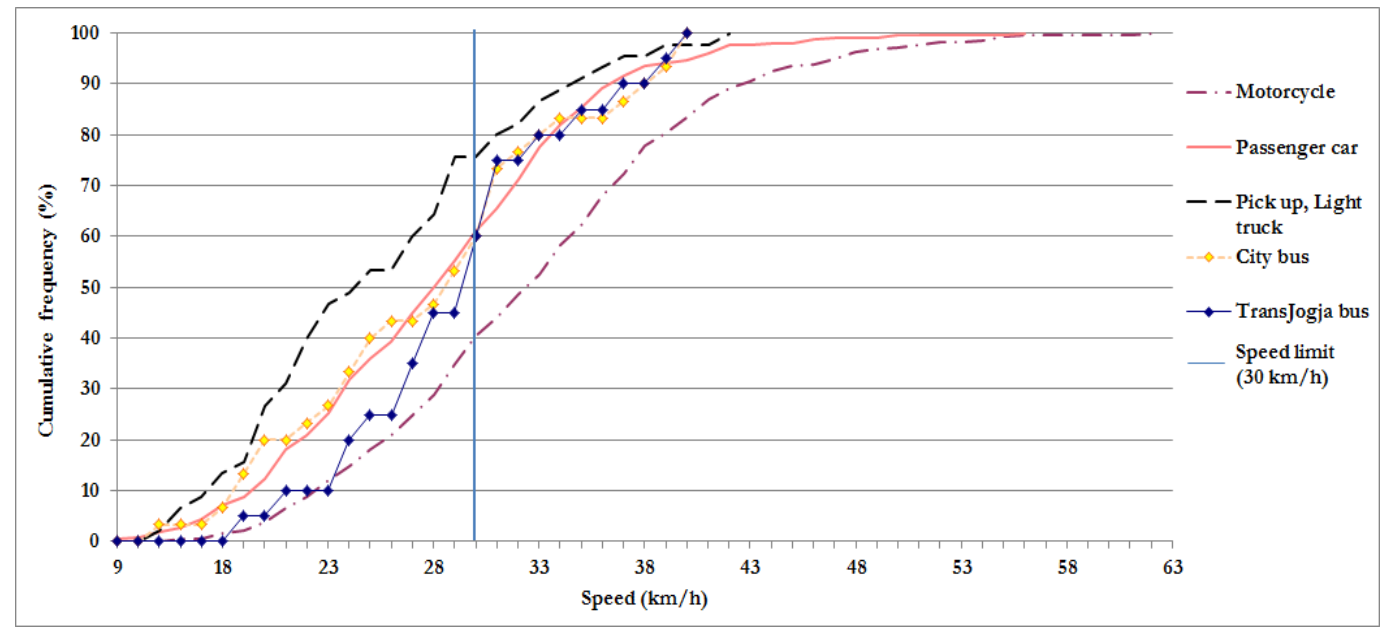

Figure 7 S-curve of vehicle speed in Malioboro Street, Yogyakarta

Table 4 Characteristics and statistical analysis of vehicle speed in Malioboro Street, Yogyakarta

\begin{tabular}{|c|c|c|c|c|c|c|c|}
\hline Statistical analysis & & $\begin{array}{l}\text { Motor } \\
\text { cycle }\end{array}$ & $\begin{array}{c}\text { Passenger } \\
\text { car }\end{array}$ & $\begin{array}{c}\text { Pick up, } \\
\text { Light truck }\end{array}$ & City bus & TransJogja & Total \\
\hline Mean $(\mathrm{km} / \mathrm{h})$ & & 33.1 & 28.5 & 25.7 & 28.1 & 29.5 & 30.8 \\
\hline Modus (km/h) & & 29.0 & 24.0 & 20.0 & 31.0 & 30.0 & 29.0 \\
\hline Median (km/h) & & 33.0 & 28.5 & 25.0 & 29.0 & 30.0 & 30.0 \\
\hline Variance $(\mathrm{km} / \mathrm{h})$ & & 63.5 & 50.5 & 44.4 & 48.8 & 30.9 & 62.9 \\
\hline Standard deviation (SD) & & 8.0 & 7.1 & 6.7 & 7.0 & 5.6 & 7.9 \\
\hline Amount of data (n) & & 400 & 250 & 45 & 30 & 20 & 745 \\
\hline \multirow[t]{4}{*}{ Percentile $(\mathrm{km} / \mathrm{h})$} & 15 & 25.0 & 21.0 & 19.6 & 20.0 & 24.0 & 22.0 \\
\hline & 50 & 33.0 & 28.5 & 25.0 & 29.0 & 30.0 & 30.0 \\
\hline & 85 & 41.0 & 35.0 & 33.0 & 36.0 & 35.3 & 38.0 \\
\hline & 98 & 52.0 & 44.0 & 39.4 & 40.0 & 39.6 & 49.1 \\
\hline
\end{tabular}

\subsection{Determining Maximum Speed Limit}

In the 1960s speed limits in Sweden were set using the $85^{\text {th }}$ percentile [22]. The $85^{\text {th }}$ percentile speed of vehicles passing a given point is the speed at or below which 85 percent of the vehicles passing the point are traveling [23]. Speed limits are set in accordance with the road design standards. Based on road function, there are three types of road i.e: arterial road, collector road, and local road. The determination of maximum speed limit based on vehicle speed at the $85^{\text {th }}$ percentile is distinguished by the type of land use i.e. residential area, office, and central business district. The maximum speed limit is distinguished by the type of vehicles that pass through in these roads are motorcycles, passenger cars, pick up or light trucks, microbus, bus, city bus, trucks, and trailers truck. Proposed maximum speed limit value based on the $85^{\text {th }}$ percentile speed of vehicles on urban road for arterial and collector road is presented in Table 5. Proposed maximum speed limit value based on the $85^{\text {th }}$ percentile speed of vehicles for arterial road type 4/2-UD residential and 4/2-UD CBD, the speed for motorcycle and passenger car at $60 \mathrm{~km} / \mathrm{h}$, for pick up and light truck at $55 \mathrm{~km} / \mathrm{h}$, for microbus, bus, city bus, truck at 50 $\mathrm{km} / \mathrm{h}$. Proposed maximum speed limit value for collector road type 2/1-UD office area, $45 \mathrm{~km} / \mathrm{h}$ for motorcycle and $40 \mathrm{~km} / \mathrm{h}$ for four-wheeled vehicles or more. While for collector road type 2/1-UD CBD, 40 $\mathrm{km} / \mathrm{h}$ for motorcycle and $35 \mathrm{~km} / \mathrm{h}$ for four-wheeled vehicles or more. 
Table 5 Proposed maximum speed limit of vehicles based on $85^{\text {th }}$ percentile in urban road

\begin{tabular}{|c|c|c|c|c|c|c|c|c|c|c|}
\hline \multirow[b]{2}{*}{$\begin{array}{l}\text { Road function } \\
\text { (type of road) }\end{array}$} & \multirow[b]{2}{*}{$\begin{array}{l}\text { Type of } \\
\text { area }\end{array}$} & \multirow{2}{*}{$\begin{array}{c}\text { Speed } \\
\text { limit } \\
(\mathrm{km} / \mathrm{h})\end{array}$} & \multicolumn{8}{|c|}{ Maximum speed limit $(\mathrm{km} / \mathrm{h})$} \\
\hline & & & $\begin{array}{l}\text { Motor } \\
\text { cycle }\end{array}$ & $\begin{array}{c}\text { Passenger } \\
\text { car }\end{array}$ & $\begin{array}{c}\text { Pick up, } \\
\text { Light truck }\end{array}$ & Microbus & $\begin{array}{l}\text { City } \\
\text { bus }\end{array}$ & Bus & Truck & $\begin{array}{l}\text { Trailer } \\
\text { Truck }\end{array}$ \\
\hline Arterial (4/2-UD) & Residential & 60 & 60 & 60 & 55 & 50 & 50 & 50 & 50 & 45 \\
\hline Arterial (4/2-UD) & CBD & 60 & 60 & 60 & 55 & 50 & 50 & 50 & 50 & N/A \\
\hline Collector (2/1-UD) & Office & 30 & 45 & 40 & 40 & 40 & 40 & 40 & 40 & N/A \\
\hline Collector (2/1-UD) & CBD & 30 & 40 & 35 & 35 & 35 & 35 & 35 & 35 & N/A \\
\hline
\end{tabular}

\subsection{The Impact of Reducing Speed Limit}

Speed limit is commonly set at the 85 th percentile speed which is the speed at which $85 \%$ of the traffic is travelling and in the USA is set 8 to $12 \mathrm{mph}$ ( 13 to 19 $\mathrm{km} / \mathrm{h}$ ) below that speed [24]. Review of speed limits for Canada identified where speed limits had been increased and decreased changes in speeding, fatalities, injuries, and property damage [25]. Effect of reducing mean speed from 55 to $50 \mathrm{mph} / \mathrm{h}$ in rural roads accident frequency multiplied by 0.86 [10]. An increase in speed will lead more accidents and more serious accidents [26].

\section{a. Impact on Proportion of Drivers Exceeding Speed Limit}

The amount of violations on an individual road depends on many different local aspects, including maximum speed limit, road characteristics, road environment, traffic density, traffic composition, and the level of enforcement in this country. The proportion of drivers exceeding the speed limit in urban road by category of road users illustrates in Figure 8 . Figure 8 shows the proportion of drivers in urban road that driving above the speed limit by category road users. For passenger car drivers, it shows that $17.25 \%$ of drivers exceed the speed limit in 4/2 UD-residential area and $91.67 \%$ in 2/1 UD-office area. For motorcycle users, it shows that $19.75 \%$ of road users exceed the speed limit in 4/2 UD residential area and $94.5 \%$ in 2/1 UD-office area. Motorcyclists represent the road user category with the highest rates of speeding with more than $46.5 \%$ of motorcycle users ride over the speed limits followed by the passenger cars users with more than $39.43 \%$ user exceeding speed limit, microbus or city bus at $31.63 \%$, bus Trans at $28.75 \%$, pick up and light truck at $24.69 \%$.

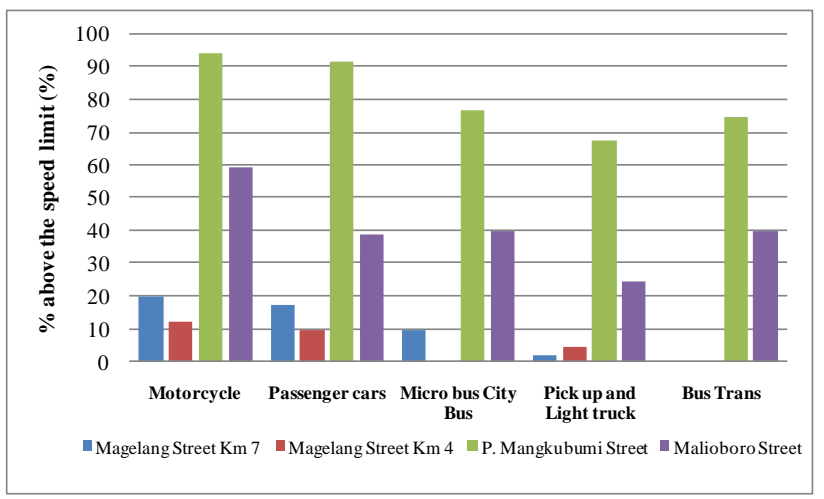

Figure 8 Proportion of drivers exceeding speed limit

The analysis results of the maximum speed limit determination, before and after installing speed limit sign and proportion of drivers exceeding the speed limit was presented in Table 6 for the speed limit 30 $\mathrm{km} / \mathrm{h}$; in Table 7 for the speed limit $40 \mathrm{~km} / \mathrm{h}$; and was presented in Table 8 for the speed limit $60 \mathrm{~km} / \mathrm{h}$.

Impact of reducing speed limit in urban road can be seen in Table 6 to Table 9. If the maximum speed limit is $30 \mathrm{~km} / \mathrm{h}$, the average speed of all vehicles decrease from 52.6 to $47.5 \mathrm{~km} / \mathrm{h}(5.1 \mathrm{~km} / \mathrm{h}$ or $9.7 \%)$ and the proportion of motorcycles ride exceeding speed limit reduce $6 \%$, passenger cars reduce $3.13 \%$, pick up reduce $6.06 \%$, microbus reduce $11.11 \%$, and trucks reduce $7.9 \%$ up to $14.29 \%$. For maximum speed limit $40 \mathrm{~km} / \mathrm{h}$, average speed of all vehicles decrease from 52.1 to $49.3 \mathrm{~km} / \mathrm{h}(2.9$ $\mathrm{km} / \mathrm{h}$ or $5.6 \%$ ). The proportion of motorcycle exceeding speed limit reduce $7.17 \%$, passenger cars reduce $5.4 \%$, pick up reduce $22.07 \%$, microbus increase $6.25 \%$, and truck reduce 19.17 up to $31.82 \%$. If the maximum speed limit is $60 \mathrm{~km} / \mathrm{h}$, the average speed of all vehicles decrease from 54.9 to $49.4 \mathrm{~km} / \mathrm{h}$ $(5.5 \mathrm{~km} / \mathrm{h}$ or $10.1 \%)$ and the proportion of motorcycles ride exceeding speed limit reduce $7.5 \%$, passenger cars reduce $16.61 \%$, pick up reduce $2 \%$, microbus reduce $9.5 \%$, and trucks reduce $4.75 \%$. 
Table 6 Speed and proportion of drivers exceeding the speed limit $30 \mathrm{~km} / \mathrm{h}$

\begin{tabular}{|c|c|c|c|c|c|c|c|}
\hline \multirow{2}{*}{ No. } & \multirow{2}{*}{ Type of vehicle } & \multicolumn{2}{|c|}{$\begin{array}{l}\text { Speed limit based on } 8^{\text {th }} \\
\text { percentile }(\mathrm{km} / \mathrm{h})\end{array}$} & \multirow{2}{*}{$\begin{array}{l}\Delta \text { Speed limit } \\
(\mathrm{km} / \mathrm{h}) \text { and }(\%)\end{array}$} & \multicolumn{2}{|c|}{$\begin{array}{c}\text { Proportion of drivers exceeding } \\
\text { the speed limit (\%) }\end{array}$} & \multirow{2}{*}{$\begin{array}{c}\Delta \text { driver } \\
\text { exceeding } \\
\text { speed limit } \\
(\%)\end{array}$} \\
\hline & & $\begin{array}{c}\text { Before installing } \\
\text { speed sign }\end{array}$ & $\begin{array}{l}\text { After installing } \\
\text { speed sign }\end{array}$ & & $\begin{array}{c}\text { Before installing } \\
\text { speed sign }\end{array}$ & $\begin{array}{l}\text { After installing } \\
\text { speed sign }\end{array}$ & \\
\hline 1. & Motorcycle & 68.0 & 61.0 & -7 km/h (10.3\%) & $96.96 \%$ & $90.96 \%$ & $-6.00 \%$ \\
\hline 2. & Passenger car & 62.0 & 61.0 & $-1 \mathrm{~km} / \mathrm{h}(1.6 \%)$ & $99.22 \%$ & $96.09 \%$ & $-3.13 \%$ \\
\hline 3. & Pick up & 58.7 & 57.0 & $-1.7 \mathrm{~km} / \mathrm{h}(2.9 \%)$ & $100 \%$ & $93.94 \%$ & $-6.06 \%$ \\
\hline 4. & Microbus & 54.6 & 53.8 & $-0.8 \mathrm{~km} / \mathrm{h}(1.5 \%)$ & $100 \%$ & $88.89 \%$ & $-11.11 \%$ \\
\hline 5. & Bus & 63.5 & 55.0 & $-8.5 \mathrm{~km} / \mathrm{h}(13.4 \%)$ & $100 \%$ & $78.57 \%$ & $-21.43 \%$ \\
\hline 6. & Light truck & 57.0 & 55.5 & $-1.5 \mathrm{~km} / \mathrm{h}(2.6 \%)$ & $97.37 \%$ & $89.47 \%$ & $-7.90 \%$ \\
\hline \multirow[t]{2}{*}{7.} & Truck & 53.0 & 51.0 & $-2 \mathrm{~km} / \mathrm{h}(3.8 \%)$ & $100 \%$ & $85.71 \%$ & $-14.29 \%$ \\
\hline & Average all veh. & 52.6 & 47.5 & $-5.1 \mathrm{~km} / \mathrm{h}(9.7 \%)$ & $99.08 \%$ & $89.09 \%$ & $-9.99 \%$ \\
\hline
\end{tabular}

Table 7 Speed and proportion of drivers exceeding the speed limit $40 \mathrm{~km} / \mathrm{h}$

\begin{tabular}{|c|c|c|c|c|c|c|c|}
\hline \multirow{2}{*}{ No. } & \multirow{2}{*}{ Type of vehicle } & \multicolumn{2}{|c|}{$\begin{array}{l}\text { Speed limit based on } 85^{\text {th }} \\
\text { percentile }(\mathrm{km} / \mathrm{h})\end{array}$} & \multirow{2}{*}{$\begin{array}{c}\Delta \text { Speed limit } \\
(\mathrm{km} / \mathrm{h}) \text { and }(\%)\end{array}$} & \multicolumn{2}{|c|}{$\begin{array}{l}\text { Proportion of drivers exceeding } \\
\text { the speed limit (\%) }\end{array}$} & \multirow{2}{*}{$\begin{array}{c}\Delta \text { driver } \\
\text { exceeding } \\
\text { speed limit } \\
(\%)\end{array}$} \\
\hline & & $\begin{array}{l}\text { Before installing } \\
\text { speed sign }\end{array}$ & $\begin{array}{l}\text { After installing } \\
\text { speed sign }\end{array}$ & & $\begin{array}{l}\text { Before installing } \\
\text { speed sign }\end{array}$ & $\begin{array}{l}\text { After installing } \\
\text { speed sign }\end{array}$ & \\
\hline 1. & Motorcycle & 63.0 & 59.8 & $-3.2 \mathrm{~km} / \mathrm{h}(5.1 \%)$ & $80.47 \%$ & $73.30 \%$ & $-7.17 \%$ \\
\hline 2. & Passenger car & 65.0 & 61.0 & $-4 \mathrm{~km} / \mathrm{h}(6.2 \%)$ & $87.96 \%$ & $82.56 \%$ & $-5.40 \%$ \\
\hline 3. & Pick up & 62.0 & 57.9 & $-4.1 \mathrm{~km} / \mathrm{h}(6.6 \%)$ & $85.71 \%$ & $63.64 \%$ & $-22.07 \%$ \\
\hline 4. & Microbus & 50.8 & 56.7 & +5.9km/h (11.6\%) & $75.00 \%$ & $81.25 \%$ & $+6.25 \%$ \\
\hline 5. & Bus & 58.0 & 62.8 & $+4.8 \mathrm{~km} / \mathrm{h}(8.3 \%)$ & $100 \%$ & $100 \%$ & $0 \%$ \\
\hline 6. & Light truck & 58.1 & 54.8 & $-3.3 \mathrm{~km} / \mathrm{h}(5.7 \%)$ & $79.17 \%$ & $60.00 \%$ & $-19.17 \%$ \\
\hline 7. & Truck & 53.5 & 48.0 & $-5.5 \mathrm{~km} / \mathrm{h}(10.3 \%)$ & $81.82 \%$ & $50.00 \%$ & $-31.82 \%$ \\
\hline & Average all veh. & 52.1 & 49.3 & $-2.9 \mathrm{~km} / \mathrm{h}(5.6 \%)$ & $84.30 \%$ & $72.96 \%$ & $-11.34 \%$ \\
\hline
\end{tabular}

Table 8 Speed and proportion of drivers exceeding the speed limit $60 \mathrm{~km} / \mathrm{h}$

\begin{tabular}{|c|c|c|c|c|c|c|c|}
\hline \multirow{2}{*}{ No. } & \multirow{2}{*}{ Type of vehicle } & \multicolumn{2}{|c|}{$\begin{array}{l}\text { Speed limit based on } 8^{\text {th }} \\
\text { percentile }(\mathrm{km} / \mathrm{h})\end{array}$} & \multirow{2}{*}{$\begin{array}{l}\Delta \text { Speed limit } \\
(\mathrm{km} / \mathrm{h}) \text { and }(\%)\end{array}$} & \multicolumn{2}{|c|}{$\begin{array}{c}\text { Proportion of drivers exceeding } \\
\text { the speed limit (\%) }\end{array}$} & \multirow{2}{*}{$\begin{array}{c}\Delta \text { driver } \\
\text { exceeding } \\
\text { speed limi } \\
(\%)\end{array}$} \\
\hline & & $\begin{array}{l}\text { Before installing } \\
\text { speed sign }\end{array}$ & $\begin{array}{l}\text { After installing } \\
\text { speed sign }\end{array}$ & & $\begin{array}{l}\text { Before installing } \\
\text { speed sign }\end{array}$ & $\begin{array}{l}\text { After installing } \\
\text { speed sign }\end{array}$ & \\
\hline 1. & Motorcycle & 68.7 & 61.6 & $-7.1 \mathrm{~km} / \mathrm{h}(10.3 \%)$ & $19.75 \%$ & $12.25 \%$ & $-7.50 \%$ \\
\hline 2. & Passenger car & 66.0 & 58.0 & $-8 \mathrm{~km} / \mathrm{h}(12.1 \%)$ & $17.25 \%$ & $0.64 \%$ & $-16,61 \%$ \\
\hline 3. & Pick up & 58.0 & 57.9 & $-0.1 \mathrm{~km} / \mathrm{h}(0.2 \%)$ & $2.00 \%$ & $0 \%$ & $-2.00 \%$ \\
\hline 4. & Microbus & 63.8 & 60.3 & $-3.5 \mathrm{~km} / \mathrm{h}(5.5 \%)$ & $9.50 \%$ & $0 \%$ & $-9.50 \%$ \\
\hline 5. & Bus & 55.4 & 53.0 & $-2.4 \mathrm{~km} / \mathrm{h}(4.3 \%)$ & $9.50 \%$ & $0 \%$ & $-9.50 \%$ \\
\hline 6. & Light truck & 58.1 & 57.6 & $-0.5 \mathrm{~km} / \mathrm{h}(0.9 \%)$ & $4.75 \%$ & $0 \%$ & $-4.75 \%$ \\
\hline \multirow[t]{2}{*}{7.} & Truck & 56.7 & 53.2 & $-3.5 \mathrm{~km} / \mathrm{h}(6.2 \%)$ & $4.75 \%$ & $0 \%$ & $-4.75 \%$ \\
\hline & Average all veh. & 54.9 & 49.4 & $-5.5 \mathrm{~km} / \mathrm{h}(10.1 \%)$ & $9.64 \%$ & $1.84 \%$ & $-7.80 \%$ \\
\hline
\end{tabular}

Table 9 Impact of reducing speed limit

\begin{tabular}{cl}
\hline $\begin{array}{c}\text { Maximum } \\
\text { speed } \\
\text { limit }\end{array}$ & Impact of changing the vehicle speed \\
\hline $30 \mathrm{~km} / \mathrm{h}$ & $\begin{array}{l}\text { Average speed of all vehicles decrease } \\
\text { from } 52.6 \text { to } 47.5 \mathrm{~km} / \mathrm{h}(5.1 \mathrm{~km} / \mathrm{h} \text { or } 9.7 \%)\end{array}$ \\
\hline $40 \mathrm{~km} / \mathrm{h}$ & $\begin{array}{l}\text { Average speed of all vehicles decrease } \\
\text { from } 52.1 \text { to } 49.3 \mathrm{~km} / \mathrm{h}(2.9 \mathrm{~km} / \mathrm{h} \text { or } 5.6 \%) .\end{array}$ \\
\hline $60 \mathrm{~km} / \mathrm{h}$ & $\begin{array}{l}\text { Average speed of all vehicles decrease } \\
\text { from } 54.9 \text { to } 49.4 \mathrm{~km} / \mathrm{h}(5.5 \mathrm{~km} / \mathrm{h} \text { or } 10.1 \%)\end{array}$ \\
\hline
\end{tabular}

Based on the analysis results obtained that the installation of speed limit signs on the highway is less effective to reduce vehicle speed. With the installation of speed limit sign, vehicle speed is reduced only about 2.9 to $5.5 \mathrm{~km} / \mathrm{h}$ (5.6 to $10.1 \%)$. This result is similar with study Malkhamah et al (2012), installing the speed limit sign in arterial road only reduce the speed in rural road 5-10\% [27]. The speed limit change was only communicated by adapting traffic signs. Parker [28] stated that "changing posted speed limits alone, without additional enforcement, educational programs or other engineering measures, only has a minor effect on driver behavior". Therefore in addition to the installation of speed limit signs also need to be coupled with the traffic management is most suitable for application in the field adjusted to the geometric roads and land use. There is a decrease in injury crashes in $62 \%$ of the 
locations after lowering speed limit from 90 to 70 $\mathrm{km} / \mathrm{h}$. There was a decrease in crash rates at intersections at $43 \%$ of the locations and $70 \%$ at road sections. In the case of the fatal and serious injury crashes, a decrease is found at $67 \%$ of the locations. A distinction between road sections and intersections showed a decrease in severe crashes at $49 \%$ and $67 \%$ of the locations, respectively [1].

Lowering speed limit will not automatically lead to a change in travel speeds. The factors such as habits, non-acceptance of the new measure or inattentiveness might explain why the actual speed adaptation is lower than the required speed adaptation [29]. Furthermore the infrastructure of the road was not adapted, which makes it less appealing for drivers to adapt their behavior, whereas others will strictly follow the rules. This can lead to an increase in the variance in travel speeds, which is an important risk factor for the occurrence of crashes [30].

\section{b. Impact on Pedestrian Safety}

According to National Highway Traffic Safety Administration (NHTSA) [31] more than $30 \%$ of accidents related to speed that causes mortality and a high social cost. Based on Figure 2, up to a speed of $30 \mathrm{~km} / \mathrm{h}$, the speed impact on fatality rate of pedestrian is $10 \%$, which means that if a pedestrian hit by a vehicle at a speed of $30 \mathrm{~km} / \mathrm{h}$, the probability of a pedestrian died was $10 \%$. Along with the addition of speed, after a speed of $30 \mathrm{~km} / \mathrm{h}$, the pedestrian fatality rate will increase dramatically. For speed of $50 \mathrm{~km} / \mathrm{h}$, the impact speed on fatality rate of pedestrian to $85 \%$ and at speed of $70 \mathrm{~km} / \mathrm{h}$, the impact speed on fatality rate of pedestrians to $100 \%$ Walz et al (1983) and the Swedish Ministry of Transport 2002 in [3]. For that, at school safety zone on hours/after school proposed the maximum speed limit is $30 \mathrm{~km} / \mathrm{h}$. The spot speed and average speed of vehicles before school safety zone relatively lower speed, but larger than the maximum speed limit $(20$ or $25 \mathrm{~km} / \mathrm{h}$ ) which allowed. The average speed of vehicle at school safety zone in peak time period can be seen in Table 10.

Table 10 Speed of motorcycle and passenger car at school safety zone in peak time period

\begin{tabular}{|c|c|c|c|c|c|}
\hline \multirow{2}{*}{$\begin{array}{l}\text { Location of } \\
\text { school safety } \\
\text { zone }\end{array}$} & \multirow[t]{2}{*}{$\begin{array}{l}\text { Peak } \\
\text { time }\end{array}$} & \multicolumn{2}{|c|}{$\begin{array}{c}\text { Motorcycle } \\
\text { speed } \\
(\mathrm{km} / \mathrm{h}) \\
\end{array}$} & \multicolumn{2}{|c|}{$\begin{array}{c}\text { Passenger } \\
\text { car speed } \\
(\mathrm{km} / \mathrm{h})\end{array}$} \\
\hline & & Lane 1 & Lane 2 & Lane 1 & Lane 2 \\
\hline$\overline{S D N} 1 \mathrm{Bobc}$ & morning & 35.45 & 35.08 & 20.73 & 31.12 \\
\hline SDN 1 Bob & after & 39.78 & 41.74 & 35.29 & 38.34 \\
\hline SD 1 Al Irsyad & morning & 24.65 & 20.23 & 17.89 & 22.38 \\
\hline $\begin{array}{l}\text { SDN } 4 \\
\text { Purwanegara }\end{array}$ & morning & 36.01 & 39.47 & 28.21 & 31.30 \\
\hline $\begin{array}{l}\text { SDN } 4 \\
\text { Purwanegara }\end{array}$ & afternoon & 38.51 & 36.58 & 36.05 & 31.30 \\
\hline Average of spe & $(\mathrm{km} / \mathrm{h})$ & 34.88 & 34.62 & 27.63 & 30.89 \\
\hline
\end{tabular}

Based on Table 10, motorcycles speed at peak time (morning and afternoon) more than $30 \mathrm{~km} / \mathrm{h}$, only in SD 1 Al Irsyad has value lower than $30 \mathrm{~km} / \mathrm{h}$. The average of speed for motorcycle in lane 1 is 34.88 $\mathrm{km} / \mathrm{h}$ and in lane 2 is $34.62 \mathrm{~km} / \mathrm{h}$. Average speed of passenger car at lane 1 is $27.63 \mathrm{~km} / \mathrm{h}$ and in lane 2 is $30.89 \mathrm{~km} / \mathrm{h}$. The average of speed for passenger car is lower than motorcycle. The result is similar with study Sugiyanto et al., (2016), average speed in school safety zone for motorcycle is $34.75 \mathrm{~km} / \mathrm{h}$ and light vehicles is $29.26 \mathrm{~km} / \mathrm{h}$ [32].

\subsection{CONCLUSION}

Based on the results, the following conclusion can be drawn: the proposed maximum speed limit based on the $85^{\text {th }}$ percentile speed of vehicles in urban road for arterial road type 4/2-UD residential and 4/2-UD CBD is $60 \mathrm{~km} / \mathrm{h}$ for motorcycle and passenger car, 55 $\mathrm{km} / \mathrm{h}$ for pick up and light truck, and $50 \mathrm{~km} / \mathrm{h}$ for bus and truck. Proposed maximum speed limit for collector road type 2/1-UD office area is $45 \mathrm{~km} / \mathrm{h}$ for motorcycle and $40 \mathrm{~km} / \mathrm{h}$ for four-wheeled vehicles or more while for collector road type 2/1-UD CBD is 40 $\mathrm{km} / \mathrm{h}$ for motorcycle and $35 \mathrm{~km} / \mathrm{h}$ for four-wheeled vehicles or more. Proposed maximum speed limit in school safety zone on hours/after school is $30 \mathrm{~km} / \mathrm{h}$. Installation of speed limit sign is less effective to reduce the vehicle speed; vehicle speed on the field is only reduced 2.9 to $5.5 \mathrm{~km} / \mathrm{h}$ (5.6 to $10.1 \%$ ). More than $46.5 \%$ of motorcycle users ride exceeding speed limits followed by the passenger cars users (39.43\%), microbus or city bus at $31.63 \%$, bus Trans at $28.75 \%$, pick up and light truck at $24.69 \%$.

\section{Acknowledgement}

"This research was carried out by the financial support of Directorate General of Higher Education, Ministry of Education and Culture, Republic of Indonesia through Research Grant "Hibah Penelitian Kerjasama antar Lembaga dan Perguruan Tinggi" and Directorate of Research and Community Services, Ministry of Research, Technology, and Higher Education, Republic of Indonesia through Research Grant "Penelitian Strategis Nasional Institusi (PSN-I)". All the contributions are acknowledged".

\section{References}

[1] Pauw, E. D., S. Daniels, M. Thierie, and T. Brijs. 2014. Safety Effects of Reducing the Speed Limit from $90 \mathrm{~km} / \mathrm{h}$ to 70 $\mathrm{km} / \mathrm{h}$. Accident Analysis \& Prevention. 62: 426-431.

[2] Nilsson, G. 2004. Traffic Safety Dimension and the Power Model to describe the Effect of Speed on Safety. Sweden: Lund Institute of Technology.

[3] Organization for Economic Cooperation Development (OECD). 2006. Speed Management. Transport Research Centre, Organization for Economic Cooperation Development (OECD) and European Conference of 
Ministers of Transport (ECMT). Paris: OECD Publishing, Paris CEDEX.

[4] Hoareau, E., S. Newstead, P. Oxley, and M. Cameron. 2002. An Evaluation of the $50 \mathrm{~km} / \mathrm{h}$ Speed Limit in South East Queensland. Journal Report No. 264. Monash: Monash University, Accident Research Centre (MUARC).

[5] Sugiyanto, G., 2018. The Effect of Congestion Pricing Scheme on the Generalized Cost and Speed of Motorcycle. Walailak Journal Science and Technology (WJST). 15(1): 95-16.

[6] Austroads. 1996. Urban Speed Management in Australia AP 118. New South Wales: Austroads.

[7] Augeri, M. G., P. Cozzo, and S. Greco. 2015. DominanceBased Rough Set Approach: An Application Case Study for Setting Speed Limits for Vehicles in Speed Controlled Zones. Knowledge-Based Systems. 89: 288-300.

[8] Hosseinlou, M. H., S. A. Kheyrabadi, and A. Zolfaghari. 2015. Determining Optimal Speed Limits in Traffic Networks. International Association of Traffic and Safety Sciences (IATSS) Research. 39: 36-41. doi:10.1016/j.iatssr.2014.08.003.

[9] Fleiter, J., A. Lennon, and B. Watson. 2010. How Do Other People Influence Your Driving Speed? Exploring The 'Who' and the 'How' of Social Influences on Speeding from a Qualitative Perspective. Transportation Research Part F: Traffic Psychological Behavior. 13(1): 49-62.

[10] Taylor, M. C., D. A. Lynam, and A. Baruya. 2000. The Effects of Drivers' Speed on the Frequency of Road Accidents. Transport Research Laboratory (TRL) Report 421, Road Safety Division, Department of the Environment, Transport and the Regions.

[11] Tapp, A., C. Nancarrow, A. Davis, and S. Jones. 2016. Vicious or Virtuous Circles? Exploring the Vulnerability of Drivers to Break Low Urban Speed Limits. Transportation Research Part A. 91: 195-212.

[12] Somchainuck, O., P. Taneerananon, and S. Jaritngam. 2013. An In-Depth Investigation of Roadside Crashes on Thai National Highways. Engineering Journal. 17(2): 63-74. doi:10.4186/ej.2013.17.2.63.

[13] Sugiyanto, G. 2016. The Impact of Congestion Pricing Scheme on the Generalized Cost and speed of Motorcycle to the City of Yogyakarta, Indonesia. Journal of Engineering and Applied Sciences. 11 (8): 1740-1746.

[14] Sugiyanto, G. and M.Y. Santi. 2017. Road Traffic Accident Cost using Human Capital Method (Case study in Purbalingga, Central Java, Indonesia). Jurnal Teknologi (Sciences and Engineering). 79(2): 107-116.

[15] Sugiyanto, G. 2017. The Cost of Traffic Accident and Equivalent Accident Number in Developing Countries (Case Study in Indonesia). ARPN Journal of Engineering and Applied Sciences. 12(2): 389-397.

[16] Ministry of Transportation Republic of Indonesia. 2009. Indonesian Law No. 22 of 2009 on Road Transport and Traffic.

[17] Wooley, J. 2005. Recent Advantages of Lower Speed Limits In Australiain. Proceedings of Eastern Asia Society for Transportation Studies (EASTS). 6: 3562-3573. Retrieved on 2009-02-15, available from http://www.jstage.jst.go.jp.
[18] Elvik, R. 2013. A re-parameterisation of the Power Model of the Relationship between the Speed of Traffic and the Number of Accidents and Accident Victims. Accident Analysis \& Prevention. 50: 854-860.

[19] Global Road Safety Partnership (GRSP). 2008. Speed Management (Road Safety Manual for Decision-Makers and Practitioners). Switzerland: Geneva.

[20] Directorate General of Land Transportation. 2005. Buku Petunjuk Tata Cara Berlalulintas. Directorate General of Land Transportation, Jakarta: Ministry of Transportation Republic of Indonesia.

[21] Sugiyanto, G., A. Fadli, and M.Y. Santi. 2017. Identification of Black Spot and Equivalent Accident Number Using Upper Control Limit Method. ARPN Journal of Engineering and Applied Sciences. 12(2): 528-535.

[22] Belin, M. 2007. Trends in Setting Speed Limits-Sweden as a Case Study. Sweden: Swedish Road Administration, Borlänge.

[23] Massachusetts Highway Department (MHD). 2005. Procedure for Speed Zooning on State and Municipal Roadways. Highway Department: Traffic Engineering.

[24] Institute of Transport Engineers (ITE). 2004. Speed Zoning Information. Retrieved on 2010-09-17, available from http://www.ite.org/standards/speed_zoning.pdf.

[25] British Columbia Ministry of Transportation. 2003. Review and Analysis of Posted Speed Limits and Speed Limit Setting Practices in British Columbia. Retrieved on 2009-0917, available from http://www.th.gov.bc.ca/publications/ eng_publications/speed_review/Speed_Review_Report.p df.

[26] Ludvigsen, H. 2007. Differentiated Speed Limits-How to Implement This Safely? Danish Road Directorate, Jesper Mertner COWI A/S, Association for European Transport and Contributors.

[27] Malkhamah, S., G. Sugiyanto, G.P. Suardika, and A. Widiati. 2012. Speed Management to Solve the Traffic Safety Issues. Final Report. Yogyakarta: Gadjah Mada University.

[28] Parker, M.R. 1997. Effect of Raising and Lowering Speed Limits on selected Roadway Sections (No. FHWA-RD-92 084). Virginia: U.S. Department of Transportation, Federal Highway Administration, McLean.

[29] McCarthy, P. 1998. Effect of Speed Limits on Speed Distributions and Highway Safety: A Survey of Literature in Managing Speed. In: Review of Current Practice for setting and Enforcing Speed Limits (No. Special Report 254). Perdue University, Department of Economics, Indiana.

[30] Aarts, L. and I. V. Schagen. 2006. Driving Speed and the Risk of Road Crashes: A Review. Accident Analysis \& Prevention. 38: 215-224.

[31] National Highway Traffic Safety Administration (NHTSA). 2005. Traffic Safety Facts 2005. NHTSA - U.S. Department of Transportation.

[32] Sugiyanto, G., M. Diaz R.P.H., M.Y. Santi, and E.W. Indriyati. 2016. The Evaluation of School Safety Zone Implementation in Elementary School (Case study in Banyumas District, Central Java Province). Media Teknik Sipil. Muhammadiyah Malang University. 14(2): 174-181. 